\title{
The Role of State Attorney General in Prevention of Crime Occurrence
}

\author{
Mahmoudreza Safraei ${ }^{1} \&$ Jafar Kousha $^{2}$ \\ ${ }^{1}$ Department of Criminal Law and Criminology, Qom Branch, Islamic Azad University, Qom, Iran \\ ${ }^{2}$ Department of Law, Shahid Beheshti University, Tehran, Iran \\ Correspondence: Mahmoudreza Safraei, Department of Criminal Law and Criminology, Qom Branch, Islamic \\ Azad University, Qom, Iran. E-mail: safraei1394@gmail.com
}

Received: June 4, $2016 \quad$ Accepted: June 29, $2016 \quad$ Online Published: June 1, 2017

doi:10.5539/jpl.v10n3p26 URL: https://doi.org/10.5539/jpl.v10n3p26

\begin{abstract}
Nowadays, wide span and diversity of new types of crime have provoked a social crisis. To prevent the crime, various reactions have been revealed in different societies. However, such responses are originated in retributive and intimidation thoughts. Public opinion and lack of knowledge in properly treating with crimes have been the main reasons why governments tend to repressive reactions, while prevention of crime occurrence topics should be considered in the first priority of crime policies of countries. Attorney general's appearance in prevention realm is complicated and sensitive and deemed as a most challenging subject. Because he in charge of public prosecutor is the keeper of individuals, social, government, people's benefits and guardian of social security. But his range of intervention is under question and is a serious and challenging argument. The present study aims to know the different kinds of challenges and available solutions in the light of explaining the dissuasive methods and also to prevent the increasing of crimes number and social security threat by the most effective tools and prevention methods and perform our duties favorably and properly in accordance with meet the needs of criminal justice goals. The method used in this study is analytic-descriptive and is prepared using library valid documents and books. We conclude that in social prevention level, the governmental organizations are not the only effective and responsible but by considering international experiences in performing patterns of prevention management, it seems that performing prevention plans through social institutions and NGOs (particularly in social prevention)is highly effective in crime occurrence prevention.
\end{abstract}

Keywords: attorney general, criminal justice, criminal policy, prevention of crime occurrence

\section{Introduction}

Attorney General has a specific position in the penal justice system in most of the judicial system of the world. By considering his qualification and his legal responsibilities, he plays an effective and valuable role in preventing crime occurrence, development of judicial prophylaxis, protection, and conservation of the whole people's rights. The basic role of this high-rank official is confronted with the process of judicial measures and constantly involves crime discovery, judicial prosecution, and trial. Hence by a framework of law, he announces the related decisions of judicial precedent direct the preliminary investigations and plays role in courts in represented of the society. In fact, a wide range of lawful power, numerous qualifications, and awareness to different kind of obstacles and social crisis have provided his directive and indirect intervention in prevention topic. It was necessary that prevention of crime occurrence be the first priority of criminal policies. Because strategies and operative programs of prevention not only prevent crime and delinquency but also increase security and improve the life quality of citizens. In a wider scope, it helps social solidarity consolidation, public order and sustainable development of countries. Also, long-term prevention leads to a reduction of the official system of criminal justice and other expenses due to crime and creates opportunities for applying philanthropic and inexpensive approaches in the context of crime. Crime increasing, its wide range, and diversity during recent years, presents a crisis that has terrible results if it is not going to be controlled. The approaches of different countries about the criminal phenomenon are originated in intimidation thought and retributivism. The present approach of criminal justice system of Iran is more originated of this approach too. Because of this, subjects related to prevention of crime occurrence are not the top priority of criminal policy of the country. There is no doubt that there is a priority to prevent and reduce crime committing contexts. Because prevention leads to a 
reduction of expenses of criminal justice official system and other expenses because crime in long-term generates opportunities to apply philanthropic and inexpensive approaches in the context of crime. To which organization is responsible for preventing crime occurrence, is the issue different in every country. In Iran, governmental organizations contributed in prevention; act separately and dependently in Executive, Judiciary, and Legislature. Social organizations, non-governmental public institutes, Islamic revolution organizations, and councils contribute in this important issue but its strategic management is conferred to the judiciary by virtue of clause 5, article 156 constitutional laws. Unfortunately, in Iran favorable and proper achievement hasn't been reached during the recent years due to different reasons that it is mainly because of lack of united criminal policy, insufficient tools and equipment and lack of responsible specialized organization and related to this issue. Prevention means "to anticipate, to precede and to preface" and also "to inform, to notify and to alarm". In lexicology, it means "preservation and repulsion" (Mohammad M, 1985). Prevention has two meaning: restrictive and extensive. In extensive concept which is considered public approach anything which opposes crime and prevents to occur or causes its reduction construed as a crime (Ebrahimi, 2009). This vision was first indicated in Enrico Ferry's thoughts of criminal policy. The individual defense which is expressed to prevent the repetition of crime and public prevention that is obtained based on collective wisdom are related to this subject. The restrictive concept of prevention (non-criminal prevention) considers restricting the possibility of crime occurrence through making impossible, making difficult or reduction of its occurrence probability without using crime threat or execution (Gassin, 1991). In this study, we mean the preventive role of State Attorney General in both concepts of prevention. Likewise, by checking power limitation, duties and qualification of this judicial high rank in the context of crime prevention, we assess and analyze its results and negative and positive outcomes.

\subsection{Attorney General Positions in Iran's Legal System and Other Legal Systems}

Attorney General as a superior rank to public prosecutor's office and naturally all public prosecutors' office of the country has a specific position. Public prosecutor's office as one of the criminal justice system tools has a considerable and impressive role in crime prevention and specialized fighting with it. Public prosecutor's office with history and experience of 220 years is known as a specialized organization. The history of public prosecutor's office refers to the time after France Revolution in 1789. Hence in any court, public prosecutor or assistant prosecutor attends to defend public rights. Subsequently, establishment and application of public prosecutor's office system in the legal system were imitated by other countries. Likewise, public prosecutor's office appeared in Iran legal system too (Hashemi, 2012). The Attorney General position in Iran laws is expressed in chapter 10 of criminal procedure code ratified in 2013 titled duties and power of Attorney General. In item No 288 to 293 of this code, the following items are expressed:

- Monitoring, inspecting and creating harmony among public prosecutor's office, revolution prosecutor's office, and military prosecutor's office and giving necessary suggestion to the chief of the judiciary and other competent authorities. (article 288)

- Appointing, substitution, job changing and service place of judicial officials of public prosecutors. (article 289)

- Following up crimes concerning properties, national and public interests and profits from competent authorities. (article 290)

- Doing research in case, that according to the law, State Supreme Court is responsible for prosecution and trial.

- Announcing the name of people denied permission to leave the country.

- Authorizing retrial to public rights and governmental claims, charities and public endowment, affairs of incapable and missing persons without a guardian in contrary to religious law in the execution of article 477(article 293).

Not only Attorney General qualifications are not limited to above-mentioned items but in some other case of this law and some other specific law he is appointed to many other duties that the most important of those duties are as follows: "membership in state supreme council of crime prevention, applying for uniform judicial precedent decision of supreme court, applying for transference of security cases, transference of judges and military court judges infraction and members of board of directors of bar association and official expert of the judiciary, retrial for final judgments of courts, to order for prosecution of judges infraction of military prosecutor's office, directorship of determining instances of criminal content committee, objection to judges' qualification and competence, directorship of central council of prevention and social protection headquarter, membership in high 
council human rights, membership in supreme council of monitoring and inspecting of the judiciary, membership in central committee of monitoring on weapons and ammunition, membership in drug control headquarter, membership in electronic trial directive council etc. Position and qualification of Attorney General are different in various countries. For instance, this issue is going to be discussed in The United States, England, France and Germany in the following:

1) The United States: in the legal system of America, Attorney General enjoys the very high-rank position and extraordinary power so that he is able to judge the president. The public prosecutor is responsible for handing over the defendant and follow up the criminal action to the end. With the help of each district court, other than the attorney, there is a state public prosecutor that serves in the executive power_and not in the judiciary_under the supervision of Attorney General. In this system, Attorney General is a member of government cabinet and is chosen and appointed as the secretary of justice by the president and has considerable power (Ashouri, criminal procedure).

2) England: Attorney General is the highest legal government's representative in England but is not a member of the government cabinet. He controls significant crime prosecution and is government counselor in legal affairs and he is the chief of the Bar Association (Ashouri, Criminal Procedure).

3) France: The Attorney General has dominance over public prosecutors. There are an Attorney General and seventeen assistant prosecutors in France Supreme Court and every district has a chief and fifteen counselors and three assistant prosecutors and a secretary. In insisting judgment cases of public council, the meetings are also held with the presence of thirty five counselors under the presidency of first district chief and participation of Attorney General. Prosecutor's office of Supreme Court is also the reference and source of the commencement of legal procedure of justice court of the republic which examines the crimes of government office. In this legal system, Attorney General has a prominent and clear position (Hashemi, Mohammad, 2012, 474).

4) Germany: Attorney General is dominant of public prosecutor's office and public prosecutor's office as a dependent organization from courts, are responsible for prosecuting criminal actions (Noghrekar, 2012).

\subsection{Attorney General's Role and Position in Prevention Types of Crime Occurrence}

It seems that the recent progress and different condition of Iran's society in comparison with the last have created extensive obstacles and problems and subsequently, a wide range of social deviation and increasing new crimes has led to the creation of crime increasing crisis. It is clear by extension of the mentioned crisis, duties and responsibilities of criminal justice organizations and specialized references for crime fighting has been increased proportionally.

Attorney General as a public prosecutor not only excluded by this rule but is assumed to have extra duty and responsibility. This is because his role in prevention and fighting and controlling of crime with respect to his legal unique powers is construed as an effective and incomparable role. As a matter of fact, his legal role and position in social security guardianship are undeniable. This position has different phases which legislature has specified diverse duties and responsibilities proportion to each phase. The above-mentioned phases can be divided into three steps: 1) prior step of crime occurrence. 2) The step of crime occurrence. 3) Afterward, step of crime occurrence. With respect to punishments goals and legal duties of apparatus and related organizations in confronting crimes, conditions, and suitability of the said steps caused the legislature's intent be with the goal of correction and treatment (rehabilitation) by using the newest justifications for applying punishment, correction and then returning the delinquent to society Phase before Crime Occurrence: In Iran, many social institutes and governmental organizations are involved with crime prevention which most of them are under control of the executive power. Therefore, according to law, no intervention is provided for Attorney General, except those powers referred due to his membership in related committees, boards, councils, and headquarters. This issue is one of law ambiguity and defect as far as any behavior behalf him may be construed as violating individual's privacy. Crime Occurrence Phase: Many and numerous powers are considered in this step which mainly refers to legal and judicial power and criminal actions. In fact, by the occurrence of crime and criminal phenomenon, the public order would be under question. Although crime may have personal aspect, at first it may have a public dimension. Crime occurrence process forms a square which on its sides the society, defendant, victim and criminal phenomenon are located and sovereignty is placed in the center. Expectations from sovereignty are to fight against crimes, crime detection, criminal prosecution, punishment execution and in the end providing victim's rights at once (Koosha, 2009). Phase after crime occurrence: In this step, most of the actions are considered to be toward punishment and defendant rehabilitation and prevention of crime repetition. Since prevention of crime occurrence is one of the extending and developing methods of security and social justice, and causes society purifying and fulfilling criminal law goals, devoting and extending to the different steps of 
prior, during and afterward of crime occurrence is quite complicated and important. Now by considering the divisions done in in the context of criminal and now- criminal prevention (social) Attorney General's role is examined on the basis if these two approaches:

1) Criminal prevention: It is divided into public and private prevention. Public prevention contains usage of intimidation aspect of criminal law particularly punishment and private prevention is to prevent repetition of crime by criminal.

2) Non-criminal prevention: This type of prevention which has economic, cultural, educational nature prior to crime occurrence by using non-repressive and non-forcible actions is done in order to socialize and legalize individuals and prevent crime occurrence in the future.

\subsection{The Role of State's Attorney General in Criminal Prevention}

Criminal prevention with criminal threat of the subjects of criminal law on one hand and executing this threat through punishment of who has violated this prohibition on the other hand is in the position of public and private prevention of crime occurrence. Repression and punishment can be dissuasive itself. So prevention and separation should not be detached but also it can be applied to decrease crimes by using each other's ability and property. Society reaction should not be just repressive (reactive) against delinquency. It is necessary to be expressed toward preventive criminal policy goals and on the basis of crime prohibition and criminal rehabilitation by using prevention plans. The most existing important issue about criminal prevention is that such preventive actions are often irreversible and cannot be remedied and it may be abused or to be violated from judicial perspective. Insisting legality in crime prevention and control is one of the key properties in democracy. In fact criminal public prosecution involves some of the most severe public and private social implementation guaranties even execution. Since the authority of criminal court is very extensive, there is a possibility that such power may be abused or enforced in wrong way (David W, Newbore, 2010). Because Attorney General is director of Prosecutor's office of Supreme Court and controls the state public prosecutor's office, he is able to play an impressive role in leading the criminal actions by directing toward prevention of crime occurrence. Of course Attorney General's role varies in every kind of criminal prevention (public and private).

\subsection{Attorney General's Role in Public Criminal Prevention}

The meaning of the public prevention is using the intimidation aspects of criminal law particularly punishment. With this argument that individual's fear of apprehension and punishment prohibit them from committing a crime. Islam has based the principal on crime prevention and not on punishment. Unfortunately prevention principle which is emphasized by different ways in Islam hasn't been paid enough attention as a criminal policy. Promoting the virtue and preventing vice in its extensive meaning, is a kin of crime prevention. The principal of not promoting the immorality and not mentioning the crime and covering up some of the crimes are some of Islamic criminal policy which has not been noticed too (Goodarzi B, 2005). Attorney General's role and subsequently state public prosecutor's offices in this kind of prevention with respect to available tools such as judicial and legal power, is faced with great importance. Because public criminal prevention can lead to unpredictable results so that its control would be impossible or would be very difficult or expensive. Thus it is necessary to protect any program implementation or action in this regard so that its negative results would be controlled and in contrast it is to be cared that no damage applies to personnel's legal freedom. For example, it can be mentioned to negative outcomes of in public severe punishments

\subsection{Attorney General's Role in Private Criminal Prevention}

The meaning of private criminal prevention is to prevent crime repetition by delinquent that is obtained by criminals rehabilitation inserted in clause 5 article 156 of constitutional law. Article 3 prison organization code ratified on 10.12.2005 has mentioned the keeping delinquents in jail, job training, rehabilitation, too. Attorney General is able to follow the prevention goal of repeat committing a crime by culpable through intensifying the monitoring of culpable punishment implementation during the punishment implementation or afterward releasing from prison protection. These programs can be done by intelligent aid and consider the particular condition of offenders. Because the criminal after passing his punishment is considered a community member (and not a member of the community) as social patient and needs help and support for rehabilitation, correction, and treatment. So far, unfortunately, nothing favorable has achieved in this regard and community keeps refusing criminals (even after punishment and compensation) from admittance. By reviewing the conditions and regulations of donating facilities and administrative services, economic and social opportunities in governmental organizations to such individuals, it is understood that such services are considered as very hard. Public point of view and even family to a criminal after releasing from prison is so negative and this face challenges socializing the criminal. Do Attorney General and subsequently prosecutor have any duty regarding his role as prosecuting 
attorney facing with strict illegal regulations to criminals (after punishment)? Is there any solution to correct regulation, codes, circulars or instructions which are against preventive policies? Answering the above-mentioned question is not easy. For example, if a regular law restricts a nation or a group or some individuals' rights against constitutional law, it is Guardian Council's duty to recognize this problem and no position is considered for Attorney General in this regard. It seems that Attorney General has general authority in a natural manner and thus is qualified in this regard but there is no legal solution except what mentioned in items No. 288 to 293 of criminal procedure code (defense against claims regarding the government). If codes, circulars, and instruction issued by the governmental organization and institutes cause a relapse of all people or a group or some individuals illegally, the administrative justice court and chief of the legislative are responsible officials to recognize and no position is considered for Attorney General to object. In article 293 of criminal procedure code ratified in 2013, it is pointed to only "fixed principals" who its contradiction with religion or law is possible, by referring to a general attorney. Of course, this fault is also in other rules and regulation related to general law.

\subsection{Attorney General's Role in Non-Criminal Prevention}

Non-criminal prevention mainly contains social prevention and situational prevention. Sometimes crime prevention is based on the necessity of felon's characters change and balance and social conditions which is known as "social prevention". Sometimes prevention or repetition of criminal phenomenon (including crime or deviation) requires manipulation and changing in an environment or specific condition. This kind of action is called "situational prevention". The other type prevention is developmental or early prevention which includes intervention in growth different stages of criminal, deviated adolescent or subjected to felony in order to prevent occurrence or become severe felony in the future and in adulthood (Mouris, 2006). In Iran the dominant imagination concerning Attorney general's qualification to intervene prevention scope, refers to his penal actions. Whereas with new the legislature's approach non-penal prevention policies has been gained specific significance. (See Family Support Code ratified in 2012, Islamic Punishment Law ratified in 2013, criminal procedure code ratified in 2013, and law of combat with exchange and goods smuggling ratified in 2013 chapter two: smuggler prevention etc.). Non-penal prevention has been established and approved clearly in penal system and criminal policies of the Islamic Republic and in other laws such as social security and welfare comprehensive system law, executive bylaw of prison organization and macro judiciary policies of country has been discussed about crime prevention and determining preventive criminal policies of Iran, yet it looks insufficient. Because First, newfound crimes are always developing and becoming modern and second, public opinion about prevention is concentrated on official actions such as correction of current laws, supporting public prosecutor's offices, mitigation of punishment and providing new definitions of crime and punishment while parallel to this actions it should be noticed to people's cooperation basic role and other related non-governmental in the field of prevention(like media's role in decriminalization, instructing and propaganda role in crime prevention., people's awareness and defense scope related to their rights and generally to effective social factors collection in prevention). The question is that how the preventive policies and plans should be taken by Attorney General in the community that it doesn't threat or damage citizen's legal rights and freedom? Answering this question requires to differentiate and check non-penal prevention subdivisions. To intervene in any area, requires designing a model and specific program and suitable to related condition.

\subsection{Social Prevention}

Social Prevention means a collection of plans and actions which follow elimination or neutralization of reasons and paving the way for crime. Social prevention is based on finding the reason of crime which wants to eliminate or neutralize the factors which affect to crime genesis and intervene to social environments to prevent the formation of criminal intents and neutralize causing offense factors. The goal of this prevention is making community health so that the preliminary crime occurrence and crime repetition can be prevented. This prevention is stable and permanent by changes and corrections in individual and community following crime prevention. in other words, this kind of prevention is following reduction or eradicating personal or social reasons affecting on felony (Beccaria, 1985). In order to reach the social prevention goals, some methods have been mentioned. Such as coordinate governmental and private organizations, preparing a preventive framework for the entire citizen's cooperation, to provide supportive services for needy, poor and destitute families, instructing parents to be aware of their kid's rights and protecting them, provide medical and hygiene cares to disabled and people suffers incurable and long-term disease, developing pre-school training programs, developing the education of law to all people etc. (Salahi, 2010). In this type of prevention, Attorney General is not permitted to intervene prior to crime occurrence. Because it associates with individual's privacy. But ha can follow and perform his preventive ratified programs with coordination, management and direct of other related and qualified organizations. It seems there is a doubt about the existence of such coherent program and policy. 


\subsection{Situational Prevention}

The situational prevention is defined as "preventive act focus on condition and situation in which crimes may be happened in that situation" and its goal is to take some measures in order to make it more difficult for the criminal to commit the crime. Criminologist has enumerated related arrangements to situational prevention which is as follows: school supporting, weekend activities, controlling kid's pocket money, not other's temptation and instigation, supporting communication and companionship with neighbors, encourage to park privatization etc (Salahi 2010). The situational preventive programs are usually admitted by political regimes because it directs concentration from enormous social projects which is necessary to eradicate the crime basic reasons toward conditions in which crime may happen (Garland, 2000). Of course there are some objections to this type of prevention. Situational prevention objections mainly contain crime displacement, ethics and human rights issue and inefficiency (Felson, 1997). Generally, preventive plans don't have definite results. Because in spite of using situational prevention methods like environmental design, giving immunity to delinquents, electronic protection of target and controlling delinquents, offence has not been controlled and crime increase is tangible in societies (Vajargah, 2011). But Attorney General can carry out thoughtful and effective actions concerning this vital and effective issue with situational preventive programs management which is performed by qualified and related organization regarding prevention (like governmental organizations, judicial executive officers etc.). Powers grant of supervision and instruction of judicial executive officers to attorneys general (clearly mentioned in article 28 criminal procedure code) has made it easy to establish dome part of the preventive goals.

\section{Outcomes of Applying Attorney General's Role in Prevention}

The outcome means result, efficiency, and also social consequence and efficiency obtained from results for community or any changes in the environment which appear as a result of organism behavior or vice versa. The outcome here means the entire wanted and unwanted, negative or positive works and results of preventive programs. However, nowadays prevention issue is at the center of the attention of related and responsible organizations in reaching criminal justice goal. In fact performing a preventive program has numerous outcomes in different aspects. Because prevention should be defined based on its outcomes and not based on of its goals. In the process of crime prevention, there may be happenings which are incongruous with predefined or unwanted variables and in some cases are contrary to the considered goals of a program. Outcome assessment is also a specialized area and has been very effective in increasing the amount of program success. It has been emphasized in many social-related areas and has a growing trend during the recent three decades (Sadeghi et.al, 2012).

Preventive intervention assessment may be divided into two general areas: scientific assessment and pragmatic assessment. In a closer looking, these outcomes can be assessed as follow:

1) Number of Criminal Events

2) Amount of prevented injuries

3) Number of violators

4) Number of injured victims

5) Number of repeat injuries

In policy and performing preventive programs, employing programs to fulfill the criminal law, safety providing, decreasing of committing crime chances and preventing committing and repeating the criminal action in the society are the main goals. But in practice, besides clear outcomes, if performing a preventive program leads to unwanted outcome occurrence which is hidden in the performance procedure and its processes, unwanted events and outcomes are construed as a program that it may lead to crime increasing and threatening of the efficiency of social institutes which are involved in crime prevention. The limited recent research represents the unconsidered intervention and lack of theoretical basis and harmful outcomes like intensifying delinquency condition, loss of energy and limited power of related crime prevention organization deviation of crime control policies, giving exaggerated statistics of programs and plans results and generally entails preventive intervention (Farajiha, 2008). In fact, the outcome of each program should be predicted before execution and assessed and analyzed after execution. However, in checking the execution outcomes of a plan, lack of reliable statistics about crime and felony quantity for a success evaluation of a plan, is construed as a significant obstacle. Of course, results and consequences obtained from preventive programs vary and in a general categorizing, it can be discussed and divided into criminal and non-criminal preventive program. The execution outcome of criminal preventive strongly depends on programs essence, how to execute, and expertise of responsible and executive organizations, 
time and execution of programs while it is totally different with the execution outcomes of non-criminal preventive programs in light of variables. The natural of programs to be scientific and coincident to crime condition and situation and the method and the way it is going to be executed are important in fulfilling to its goals. Positive and Negative Outcomes: showing crime ugliness and punishment intimidating, preventing to impose prison costs, preventing committing a crime by life imprisonment convicts, reassuring the survivors, and witnesses of objective incidents and reassuring them to justice running and also establishing central government power are positive outcomes of execution. However, this point of view is criticized by many scientists and international organizations. In fact, we mean Attorney State General's role is playing a role in which preventive policies and plans are predicted in the aspect of quality, methods, and ways of performing predicted punishments and to be conveyed to all public prosecutors in the country. Even in the case of execution which is inevitable legally, proper treatment to convict's family, considering Islamic ethics, not violating of court's order etc. can be emphasized and should be considered. For instance, it is necessary that outcomes and workability of two issue, intimidation of actions and debilitation in different times and places, (with respect to apparent, hidden, positive and negative outcomes) to be examined scientifically and exactly. Or in another example, non-criminal preventive (includes social and situational), it is critical actions outcomes (depends on its nature) to be controlled and these process control actions and feedback is used constantly to update plans. In this regard, the outcomes multi plans about crime fighting which has been performed in Iran during recent years will be discussed. Plan of fighting with rascals and hooligans phenomenon and prevention thereto: this plan due to its nature and striking and temporary property (and scientific weakness too) leads to different outcomes such as identifying, organizing and creating a background for more extensive crimes (Sadeghi et.al, 2012).

Table1. The outcomes

\begin{tabular}{|c|c|c|c|}
\hline Title of Program/Plan & $\begin{array}{l}\text { Outcome } \\
\text { Type }\end{array}$ & Theoretical Concept & Outcome/Result \\
\hline \multirow{5}{*}{$\begin{array}{c}\text { Social Security Promotion } \\
\text { Plan(Disciplinary to Fight with Rascals and } \\
\text { Hooligans) }\end{array}$} & Positive & Improving Security feeling & $\begin{array}{l}\text { Decreasing people's fear of } \\
\text { rascal sand hooligans }\end{array}$ \\
\hline & \multirow{4}{*}{ Negative } & $\begin{array}{l}\text { Social and Economic Costs } \\
\text { of Criminal Justice System }\end{array}$ & \multirow{4}{*}{$\begin{array}{c}\text { Extravagant Cost } \\
\text { Violence Promotion } \\
\text { Social Curse of Criminals } \\
\text { Improvement of Committing } \\
\text { Crime Methods }\end{array}$} \\
\hline & & Violence Propagation & \\
\hline & & Social Curse of Convicts & \\
\hline & & $\begin{array}{c}\text { Organized Criminal and } \\
\text { Offence }\end{array}$ & \\
\hline
\end{tabular}

Positive Outcomes (Improving Security Feeling): In the implementation of social security improvement plans and collecting rascals and hooligans from public communities, the created mental outcome is people's fear to be decreased. In fact, this feeling regardless of the real crime reduction is a success itself in the implementation of the plan, because criteria of preventive program assessment are not only subject to crime reduction statistics. Negative Outcomes (Organized Criminals): To control the outcomes of the program it is necessary to prevent the changing of crimes from individual state to organized state as much as possible. Because generally criminals are intelligent and compare the advantages and disadvantageous or its risk and to provide their profit and interest, they decide to participate in organized groups. Then, addition to committing the former criminal acts, they are encouraged to commit more severe crimes such as drug, goods and human smuggling than before.

\subsection{Negative Outcomes (Violence Propagation)}

Some violence and not humanity encounter which is performed in temporary and striking plan such as social security improvement plan, fighting with rascals and hooligans and chastity and hijab by helping of beating, unnecessary and illegal apprehension and etc. however it may be effective temporary, but it will lead to the outbreak of negative outcomes on criminal and community and also unfavorable and not compensated results and it helps violence widespread in society (Sadeghi et.al, 2012). Attorney General in performing his public prosecutor role in the scope of the country has a significant role in creating a uniform judicial precedent in public prosecutor's office and promote and direct them toward desirable condition and monitoring in conjunction to legal sanctions coordinating and congruence in important international and interior issues. On this basis because 
of significance and effectiveness of his actions regarding interior and international security, it is necessary the models and preventive plans in a different scale and efficiency and feeds backs of plans execution (in proportion to target community) to be evaluated constantly. It is clear that processes correction sand modernizing of models and plans (by using findings of future research of the said field) lead to the increasing possibility of plans success. Some plans that need an examination of preventive actions outcomes and modernization of fighting with offenses methods are as follows:

Fighting with Organized Crimes and Criminal Networks in Interior and International Scope:

For instance, the most important effective issue in organized crime reduction is formulation and execution of proper criminal policy and reinforcement of fighting tools with these crimes. Signing a contract and regional and international judicial communication for judicial, assistance and police cooperation etc. are also effective (Nateri, 2004). Formulating instruction of Attorney General's legal intervention methods for cooperating and directing of macro policies should be prepared and performed. Analysis of positive and negative outcomes of dynamic and efficient criminal policy execution in fighting with organized crimes and also signing contracts and international judicial communications can lead to modernization of tools and equipment also modernization and correction of methods and solutions which its least result is awareness and access to the last criminology findings, processes improvement and increasing of success possibility in intervention programs. Fighting and decisive contact with drug and psychedelic crimes (production, cultivation, transit, purchase and sale) can be considered as two important factors. The execution punishment has many outcomes. Negative outcomes for remaining members of family and executed families of drug crimes are their children's deviation and their wife's moral corruption, lack of irrevocability of innocent defendant convicted to execution, human rights and international criticism to state law system especially to public execution etc. but it should be noted that imposing the negative outcomes of such crimes to state law system is under influence affected by many social factors that sometimes is out of control (Kazemi, 2015). We will address these factors in social outcomes section. It seems that Iran criminal system has no united criminal policy in drug-fighting and depending on different legislating and judicial periods, different policies have been taken. As an example, the number of drug crimes' prisoners has been increased to 220 thousand from 150 thousand at the present time. In Iran, execution is the punishment for drug crimes. While it is proved nowadays that severe and strict punishments have not been able to reduce the number of drug crimes. Execution as punishment is the most severe criminal reaction to drug smuggle in Iran and some other countries such as the United States, South Korea, Malaysia, Thailand, Turkey, Egypt, China, India, Iraq and etc. examining the criminal policies of countries shows that by appearance of different criminal thoughts the legality of execution as punishment has become unstable and in some countries has been omitted from the punishment list because, in international scale, there is a general consensus about eliminating this punishment. In some other countries it has become inactive law and in several, the number of performing this punishment has been minimized to the least (Ansel, 1986). This expresses the flexibility, kindness, and constitution of the criminal policies of the countries. Like the modern criminal law branch of Germany based on punishment should not exceed the public deterrence of crime committing, social assistance and prevention of repeating crime as much as possible (Yeshk, 1989). By considering the supporters' and opponents' arguments, the execution punishment which existed up to now, the deterrence function of execution in Iran legal system (as a Sharia- based system) the nature of the mentioned crimes in the aspect of Islamic law need to be thought about. The question is what kind of effects does performing execution in drug crimes have on deterrence of such crimes in Iran law system? Due to the separation of deterrence from efficiency, it seems that the execution in discussed crimes is efficient enough but this it doesn't have enough deterrence in these crimes. So in the present condition, examining this issue is necessary for the aspect of the Attorney General's role of public prosecutors, in the aspect of correction of criminal policy of crimes and in the aspect of Islamic law to reach a scientific and practical conclusion. Because this kind of punishment couldn't provide the present society demands and on the other hand couldn't provide the requirements of Iran contemporary law system and in contrast it had led to revealed and hidden outcomes which its effects need to be analyzed and examined in different juridical and social aspect and in different positive and negative dimensions.

The other issues whose designing program and outcomes control can be examined are as following:

1) Effective control on function and instruction of judicial executive officer with emphasis on criminal justice

2) Preservation and protection of citizen's rights and human rights.

3) Playing a role in the international community and increasing communication with judicial systems.

4) Supporting safe and prolific investment and playing a role in providing safety economic system.

5) Protection of the environment, treasury and etc. 
Complaints, discords and cases decreasing in public prosecutor's office and judicial courts can be mentioned as the positive legal-judicial outcome. But decreasing the number of cases doesn't suffice. Because reduction of case entrance to the judiciary is not necessarily the sign of claims decreasing or peace and compromise but strengthening the peace and compromise spirit, equality and brotherhood and respect to rights of other people depend on development and expansion of public rights and attention to judicial health of the community. Because by improving the community, growth and evolution atmosphere is achieved under influence of scientific-professional thoughts of the Islamic Republic of Iran macro policies. In fact, the existence of judicial community and healthy judicial proceeding requires constant observation of criminal actions, modernizing tools and fighting methods of crimes and leading the society to desirable condition. In this case, we need the decrease of crimes and offences, and consequently, the crime rate must have descending rate, and the continuation of such process, will lead to the decrease of crime frequency, access to executive strategies compatible with prevention between public and private organizations, recognizing the method and strategies of the opportunities for committing crimes, close cooperation in all areas, design of prevention model compatible with different crimes and environmental conditions, representation of strategy in the process of crime prevention (before and after the occurrence of crime) will be considered as horizons and goals before us, in order to decrease the crimes in the future. General attorney's executions have got different and remarkable judicial implications. Knowing about the executions will prevent the occurrence of crimes and related damages. The fulfillments of such important issues require the existence of effective and regional criminal policy, and compatible with exigencies of world new community concerning crimes and how to fight with them, and as well as the right role of attorney general, considering his own authorities and qualifications.

\subsection{Social Outcomes}

Social influences and outcomes of applying for attorney general's role in an extensive manner. For instance, as mentioned in judicial and legal outcomes section, drug crimes and its punishment have social outcomes too. Imposing negative consequences of drug crime punishment (execution or public execution) to legal system and community is very serious. It should be noted at the same time that social crimes and deviations such as drug smuggling are affected by many social factors which sometimes are out of controls of individuals and criminals. Opportunities equality, social and economic justice, occupation and business booms, equal distribution of wealth and law equality are factors which affect on individual's tendency to social anomalies as a drug, should be used as the last solution as much as possible until there is such condition in the community. Hence, applying Attorney General Role affects the social outcomes. For example, there are different comments in the case that public execution is right or not. From the perspective of sociology, excessive repetition of this kind of punishment makes it less important or ineffective. The other research results present negative effects and terrible consequences of performing such punishments in the society. In social psychologists and sociologist's point of view, this leads to the increasing of invective behaviors in the society. Also, the other negative outcomes of this punishment are supporting the violence, revenge and aversion spirit, increasing the amount of homicide and aversion tolerance and normality of crime in the society. Observing a public execution has dangerous and repairable consequences for a different class of the society, especially it has severe effects on kids. The main goal of such punishment is to give an example. But the question is that this kind of punishment has its impact on the decrease of crime? Has the result and outcome of this punishment examined with statistics information? The answer is negative and such actions just hurt People's spirit and cause violence (Kazemi, 2015). Success in taking young's cooperation in policies and related processes to prevention such as using resources, community facilities, young people's self-help and victim's compensation and financial help plans, increasing the ability of organizations related to social prevention and equipped with scientific and expert power, public access to equal and justly opportunities, promoting and training of public opinion to crime condition in the country and its fighting with methods as prospects and ahead goals to reduce crimes are on top of the outcomes of performing plans and preventive policies. Human and social capacity concentration management, decreasing of administrative corruption in governmental organizations, creating a healthy environment for business and preventing wastefulness and squander are other effects of applying for this role.

\section{Conclusion}

Reaching result in preventive programs requires special attention of triple powers and appearance of preventive strategies in judicial bills and constant communication with the entire preventive related organizations. Providing comprehensive tools and facilities for prevention in the country is one the most important factor to playing his role. Thus, it requires gathering all facilities and capacities of the country to temporary reduce the crisis effects of crime increasing, delinquency increasing, lack of judicial expert policy consequences and created prolongation of the procedure. Attorney General preventive roles reflect in criminal and non-criminal dimensions. 
It seems that the main emphasis is on deterrence, punishment and its effect on crime decreasing. In criminal dimension, the main policy of deterrent view is based on criminal punishment threat or to perform that in order to reduce crime motivation and as a result, deterrent strategies and programs are more concentrated on judicial-disciplinary (afterward crime occurrence) preventions and preliminary preventions which observes the crime conception step, has not established as the first criminal policy of the country. Presenting crime ugliness and punishment intimidation for the society, to prevent imposing prisons expenses, to prevent crime committing by life imprisonment convicts, to condole remaining members of family and witnesses of objective incidents and reassuring them to justice running and also establishing central government power are positive outcomes of criminal execution but none of these can provide preventive goals of an efficient criminal policy. Unfortunately, sufficing to responsive actions to crime and resorting to trivial and incomplete effects of punishments performance, cause weak action in non-criminal dimension and ignoring multi-institutions approach and lack of attention to victim-based, community-based and environment-based prevention plans. Attorney General action in the non-criminal preventive field (social) is very serious, complex and is one of the most challenging issues. Because first Attorney General is a judicial high rank that his qualification in prevention topic refers to criminal prevention and second he as public prosecutor is the keeper of individual, society, government and nation profits and guardsman of social security and in the dominant view his intervention to prevention field is permissible on condition that a crime has occurred or there's a necessity. Otherwise, entering to personnel's privacy and violating International and state statute and regulations (citizen and human rights) is mentioned. The most important requirement is keeping public rights. An efficient and dynamic penal law should clearly specify his range of intervention in prevention so that in excuse of social detriment which is the goal of the penal law, freedom of citizens faces no limitation to cause to lose its more value. In contrast, applying the non-criminal preventive methods by Attorney General which have significant importance in the present time by crime widespread should not be neglected. Considering these two goals is so difficult, complex and challenging action. The existence of proper structure to operate crime prevention in Iran is the most important concern and the most basic ahead challenges. Because in the recently legislated law, no attention has been given to disadvantageous of being prevention structure official and NGOs and it decreases the effectiveness of the preventive plans. In fact, the formation and structure of state Supreme Court should be designed with respect to the serious and great duties and responsibilities. The "crime prevention office" that doesn't exist currently should be reestablished and start its activity as deputy of crime prevention of Attorney General. It seems that crime-proneness and decriminalization due to abovementioned structural faults and defects are notable. Because the decriminalization mission of current structure and formation cannot suitably come to existence. Lack of existence of coherent mechanism and plan and the way of responding to client and etc. are the additional reasons. Strategic management of crime prevention requires step by step and constant definition and identifying crimes and detriments, policy making, providing models and preventive plans, constant assessment and monitoring on preventive plans and pursuing and taking feedback from them. In this cycle, the most important level is assessment and monitoring (taking feedback) and subsequently correction and review thereof. As mentioned earlier, in social prevention level, the governmental organizations are not the only effective and responsible but by considering international experiences in performing patterns of prevention management, it seems that performing prevention plans through social institutions and NGOs (particularly in social prevention) is highly effective in crime occurrence prevention but it should be noted to preventive plans performance in addition to application. Unpredictable events may appear in the time of performing a prevention plan and in its performance process (events of the unwanted plan) which may cause crime widespread and limitation of effective social institution application in crime prevention. Identifying such hidden events is possible by using qualitative methods and discovery studies which have been neglected so far. Designing and performing a national and effective model of social prevention for fighting with crimes in State Attorney General and conformity and coordination control of other used models with this model is essential. After designing models and plans in different prevention dimensions by constant control of processes and taking feedback of plans, it is worth their efficiency proportion with goal community to be assessed and in the end eventually acting to correct and modernize them by using future research findings of the said field. It depends on different variables which pattern or structure with what level of relations and application will be confirmed or will be favorable. Such as number, type and reason of the crimes, the way of crime distribution, criminals type, considered plans to prevent crime etc. which should be designed and acted by consulting to academic experts.

\section{Future Outlook}

- The Attorney General should pick and employ reliable and educated counselors to consult with them about different and important legal, judicial, social, economic and political issues and topics related to his duties and 
qualifications (which is the member of different councils, commissions and boards and plays a role in directing and controlling thereof).

- Improving the criminal policy in the country requires monitoring and constant correction of processes and procedures and this can be extended to judicial and executive criminal policy besides legislative criminal policy. It deserves to create an expertise group in the field of crime occurrence prevention to examine the different aspects of prevention and to update performed criminal policy achievements. Eventually, by examining the current criminal policy and effects thereof convey and pursue the dynamic and effective criminal decided policy correction to all related organizations.

- Increasing responsible and related organization capability to fight crime in the execution of preventive policies through training, access to modern equipment and tools and deciding a right and efficient mechanism for coordination and communication of related organizations.

- Try to keep human munificence and strengthening of the entire community character and self-esteem in criminal preventions, strengthening of religious belief in social prevention and emphasis on keeping individual's privacy and limitation of personal legal freedom in types of non-criminal preventions.

- Creating an operative headquarter including jurists, sociologists and other related experts with the cooperation of triple powers in State Attorney General in order to apply scientific, practical and legal realistic methods (with society-based approach) to organize the effective and dynamic criminal policy all over the country. Examining suitable solutions to promote State Attorney General role in crime occurrence prevention and then all public prosecutor's office of the country. It deserves that Attorney General considers punishment deterrence effect and performance outcomes thereof in his all programs, action, and duties.

- The existence of proper structure to operate crime prevention in Iran is the most important concern and the most basic ahead challenges. Because in the recently legislated law, no attention has been given to disadvantageous of being prevention structure official and NGOs and it decreases the effectiveness of the preventive plans. In fact, the formation and structure of state Supreme Court should be designed with respect to the serious and great duties and responsibilities. The "crime prevention office" that doesn't exist currently should be reestablished and start its activity as deputy of crime prevention of Attorney General. It seems that crime-proneness and decriminalization due to abovementioned structural faults and defects are notable. The correction of structure and formation of can significantly help decriminalization and prevention. It is also necessary all governmental organizations and related institutions in prevention issue, correct their structure and formation proportion with their delegation of authorities missions by virtue of the abovementioned law and considering the state crisis condition and work under the directorship and concentration of the judiciary.

- The concentration of crime prevention law is not based on the nature and types of prevention. Thus, using problem-based approaches is suggested against the bureaucracy-based approach. The orientation of crime occurrence prevention arranged top toward down and this is notable because the effective structure is a structure to delegate authority of crime prevention responsibility to societal and non-governmental organizations (even in local level).

\section{References}

Beccaria, C. (1995). Crimes and Punishments, translated by Ardabili, M. A., Shahid Beheshti University,

Criminal procedure law ratified. (2014).

Ebrahimi, S. (2009). The restrictive and extensive approach to prevention and its effects, the journal of legal instruction, Razavi University, No.21.

Farajiha, M. (2008). Assessment of police preventive interventions. methodology and policy making challenges.

Felson, M., \& Clarke, R. V. (1997). The ethics of situational crime prevention, Clarke, R. V and Goriashoham, S, rational choice and situational crime prevention, dartmouth college press, p.201.

Garland, D. (2000). Ideas, institutions and situational crime prevention, A. V. H., D. G and A. W. Ethical and social perspectives on situational crime prevention, Oxford, Hart press, p.14.

Gassin, M. (2006). Criminology principle, translated by Seddigh, M.R, Dadgostar Press, Tehran.

Gassin, R. (1986). New trends in England and North America criminology, translated by A, H. N, journal of faculty of law, Shahid Beheshti University.

Gassin, R. (1991). Practical criminology, translated by Keynia, M, Allameh Tabataba'i University, Tehran.

Hashemi, S. M. (2012). Islamic Republic of Iran Constitutional Law. Sovereignty and political organizations. 
K, M. A. (1986). Execution as Punishment, translated by Rahimi, M, Agah Press, Tehran.

Kazemi, M. (2015). The effect of execution punishment on deterrence of drug and psychedelic drug crimes, Ph.D. Thesis.

Khanalipour, V. (2012). Crime's professional intervention. Mizan press.

Kousha, J. (2009). Scientific conference of Iran and Europe Judges.

Madani, S. J. (2008). Comparative Constitutional Law, Paydar Press.

Moazzami, Sh. (2007). Criminological Prevention, Majd Research Journal.

Moein, M. (1985). Persian culture, Sepehr-e-Iran printing office, Amirkabir press.

Mousavi, S. D., \& Javadi, H. (2013). Examining the new models of the adolescent and the young delinquency with emphasis on preventive strategies: National conference on Iran criminal policy for childs and adolescents criminal and delinquency.

Newborn, D. W. (2010). Translated by Gharagozlou, H. R, Criminal justice system and the structure of American courts.

Noghrehkar, M. S. (2012). Prosecutor in the scale of human and citizen rights. Jungle Press.

Principles and theoretical foundation of crime prevention. (2012). Collection of judicial papers, Journal of police.

Sadeghi, F. et al. (2012). Assessment of social outcomes of crime preventive programs, Urban public spaces (case Study: Rascals and Hooligan Phenomenon), Iran social Issues, $3{ }^{\text {rd }}$ year, No.2.

Salahi, J. (2010). Introduction to criminology and victimology.

Shams N, M. E. (2001). Iran criminal policy for organized crimes with international criminal law approach, $\mathrm{Ph} . \mathrm{D}$. Thesis, Tarbiat Modares University, Faculty of Human Science.

Yeshk, H. H. (1989). New criminal law of federal republic of Germany in testing, translated by Ashouri, M, bar Association Journal.

\section{Copyrights}

Copyright for this article is retained by the author(s), with first publication rights granted to the journal.

This is an open-access article distributed under the terms and conditions of the Creative Commons Attribution license (http://creativecommons.org/licenses/by/4.0/). 